\title{
Dialog and confrontation Conference on social pedagogy and social policy in 1967
}

\author{
For if we reach to the heritage of our educational past, \\ it is not to transfer old patterns, often outdated, into new conditions, \\ but to better understand contemporary educational problems \\ and to be able to solve them \\ Wroczyński 1968, p. 24
}

\begin{abstract}
A B S T R A C T: The subject of the article is the relation between social pedagogy - the so-called real socialism, seen in the perspective of the nationwide conference on social pedagogy and social policy held in Warsaw in 1967. This forgotten today, but important event was another attempt at the process of positioning social pedagogy in the political, social and scientific realities of the time. It was aimed at showing the place and role of this discipline of education in building the so-called socialist system. During the conference there was a dialog and confrontation between two fundamental ways of understanding social pedagogy: the "traditional" one, in accordance with the concept of Helena Radlińska, and the "socialist" one, corresponding to the principles of the political system of the country building a "developed socialist society". A visible result of this discourse was the concept of a "third space": social pedagogy, which, while maintaining the traditional ideological and scientific objectives, was engaged in solving current civil, educational, cultural and social problems. In this perspective, the primary influence of historical and social factors on the development of social pedagogy, its ideological foundations, theory and practice is sometimes revealed.
\end{abstract}

KEYW ORDS: Social pedagogy, social policy, Helena Radlińska, real socialism, Polish Free University Association, political and educational discourse. 
The 1960s were an important stage in the development of social pedagogy in Poland. At that time the heritage of Helena Radlińska (1879-1954), the founder of this discipline of education, after years of "Stalinist silence" (1948-1956) found itself again in the field of academic work and in social life (see Theiss, 2018; Modrzewski, Sipinska, pp. 103-126) At that time, the National Congress of Social Pedagogues took place in Warsaw in 1957, on the wave of the country's de-Stalinization under the slogans of democratization and the rule of law. This meeting, organized by the Polish Free University Association, was held on 20-22 January 1967 in Warsaw. The conference, like other initiatives of the community of social pedagogues of that period (e.g. publication of collective works by Helena Radlińska, 1961-1963), was carried out under conditions of "building a developed socialist society" (Bieńkowski 1978, pp. 24-27), in the space of the "system of dogmatic authoritarianism" (Lutyński 1990, p. 121).

In the 1960s our country was slowly evolving from a post-Stalinist phase into a period of so-called small stability and real socialism. The dogmas of communist ideology remained inviolable, the principle of party leadership was in place, and any attempts to depart from this approach were considered "revisionist heresy". The party authorities then made an attempt, as Maria Hirszowicz writes, to "resuscitate" Marxist theory, which in its new form was to be free from Stalinist mistakes and distortions. This did not mean abandoning the "party watchfulness" towards social sciences, especially sociology. It was quite the opposite. The party was of the opinion that: "researchers should act with full responsibility and awareness that their research is a political and ideological fact" (Hirszowicz 2001, p. 217 et al.; see also Degen, Hübner 2006, p. 11-38; Kraśko 1996, p. 229-231).

The scope of these criticism and party directives also included pedagogy, as well as psychology. Practicing science, especially social sciences and humanities, meant balancing on a thin rope between, on the one hand, democratically understood freedom and independence and, on the other, control and obedience to the rules imposed by the dominating system. In social practice, the model of "political pragmatism" was evolving and strengthening. It was a specific mixture of conformism and pragmatism, built on the foundations of positivist organic work. This was the ground on which various behaviors, attitudes and phenomena emerged and developed, such as: relativization of values, opportunism, careerism, coteries and fractions 
(Hirszowicz 2001, pp. 205-213). In many cases - it is worth noting - the models of political, social and scientific careers and patterns of everyday behavior that emerged at that time proved to be permanent. They survived for many years in order to function in their original form, after a slight ideological lifting, in the reality of the Third Republic of Poland.

How did the aforementioned conference on social pedagogy and social policy of 1967 stand against this background? To what extent was it a scientific and social undertaking, and to what extent a propaganda and political one? Or was it rather connected with the tasks of science solving real problems, or was it a façade, compromise action, based on half-truths, that was typical of those times? It is difficult to give an unambiguous answer to these questions, which were posed in response to Jan Lutyński and his concept of the psychological consequences of real socialism (Lutyński 1990, pp. 121-218).

From a general perspective, one can put forward a thesis that the presented conference was a continuation of the process of positioning social pedagogy in the political, social and scientific realities of the time, which was undertaken after 1956. It was about manifesting - true or apparent commitment and support for the party approach and the scientific policy of the socialist state, while showing the important place and role of social pedagogy and social policy in the so-called socialist construction. Certainly, for some of the participants in that conference, the participation of social pedagogy in the construction of a socialist state was a genuine, important task, in line with the shared and accepted values (see Smolińska-Theiss, Theiss 1998, pp. 172-180).

The records of the analyzed conference, included in the TWWP (Polish Free University Association) bulletin "Człowiek w Pracy i w Osiedlu [Man at Work and at Home]" (1968, no. 1), are a record of a complex educational and political discourse. Social pedagogy - the central concept of this discourse - was analyzed, interpreted and evaluated in terms of various perspectives: ideological and scientific, historical and contemporary, current and designed, approving and critical, direct and indirect, theoretical and practical, and so on. However, regardless of the type and content of the statements, all of them were constructed in relation to power, taking into account the model of state and social life imposed and enforced by the party (see Misztal 2000, p. 73).

\section{II}

The organizer of the conference was the aforementioned Polish Free University Association. At the time, it had been operating for 10 years and 
belonged to well-known social and educational institutions in Poland. The cofounder and long-term president of the Association, Adam Olgierd Uziembło, a mathematician and pedagogue, gave this institution the shape of a thriving research center based on grassroots scientific initiatives, which had its divisions throughout the country (see Theiss 1998; 2007). The conference was attended by over 600 research workers and social activists - members of the Association. The prestigious halls of the Palace of Culture and Science in Warsaw were chosen as the venue of the event. The reference about the conference titled "Pedagogy and social policy", published in the central party newspaper "Trybuna Ludu [People's Tribune]", was of great propaganda significance. The essential role and contribution of A.O. Uziembło to the organization of the conference was appreciated and emphasized by A. Kamiński. In the letter addressed to him dated 4 February 1967 he wrote: "Dear General! Having cooled down after the conference - I would like to thank you once again very sincerely for the extraordinary event that you organized, and which gave the social pedagogy a chance to go out into the wide waters of science. I am now looking forward to my role as a consultant in compiling a collection of conference materials on social pedagogy." (Listy 1997, p. 202). Jan Szczepański spoke in a similar spirit while opening the conference: "without his (Uziembło's - added by WT) energy and passion, his youthful enthusiasm, his prudent wisdom and iron consistency in action, this conference would probably not have taken place" (Szczepański 1968, p. 17).

The conference had the status - as it was then written - of a party and government event. It was attended by various representatives of political and social life, ranging from representatives of high state and party authorities, through a group of youth organization activists, to well-known figures of the world of science, social pedagogues and socio-educational activists. Some of the participants of this meeting, standing on liberal-democratic grounds, belonged to the "previous epoch", while others, being in line with the Marxist world view, represented the "avant-garde of the times of socialist construction". The first ones - to reach the distinction proposed by Kazimierz Przyszczypkowski - by agreeing to "politics in education", acknowledged that political commitment or loyalty can be reconciled with other goals, e.g. educational goals. The others, believing that education in general is political, i.e. accepting the "politics of education", treated the conference as a form of "participation of science in building a new system". (Przyszczypkowski 2012, p. 37 et seq.). This duality of the event of an - even! - surrealistic character was noticed by the aforementioned Szczepański. He noted in his journal: 
21 January (1967): Yesterday morning I officially opened the conference on social pedagogy in the Cinema Hall on the 6th floor of the PKiN [Palace of Culture and Science]. I gave a short, ceremonial speech and then we elected T. Kotarbinski to be the honorary chairman and asked him to pay tribute to the memory of Helena Radlinska. Then Kotarbinski awarded the medals of the 1000-year anniversary, the opening was filmed, the hall was full, several hundred people, the press. It seems to me that this conference is proof of the surrealism of our people's and communist state. The organizer of the event is the Polish Free University Association, which gathers a group of elderly men who are eager to reminisce about their young years. The conference was a rehabilitation of Helena Radlińska. Some attacked her, others defended her, her former pupils were a bit hysterical, in other words - a spectacle. Today there will be a talk about social policy, on Sunday the debates will be held in sections, the issues discussed will no longer be related to the controversial social pedagogy and the person of grandma Radlinska. For those several hundred people who came from all over the country, the conference has a completely different dimension than for the gossiping Warsaw groups. (Szczepański 2013, pp. 323-324).

Szczepański knew Helena Radlińska well from the time they worked at the University of Łódź. In his Dzienniki (Journals), he wrote: "9 December (1945): On Tuesday I had an interesting conversation with Helena Radlińska, who presented her "will« to me, making me her heir and executor. In other words, I am to become the head of the Social and Educational Institute at the WSGW" (Wyższa Szkoła Gospodarstwa Wiejskiego [University of Life Sciences] - WT) (Szczepański 2013, p. 21). In 1954, after Radlińska’s death, he published a memoir about her, where he emphasized the significance of her achievements in the tradition of Polish pedagogy (Szczepański 1954). Therefore, the question arises: in relation to whom, what and why did Szczepański, then a member of the social and governmental elites of the country, distance himself so clearly when he wrote about the "surrealism of our people's and communist state"? The existing political system, Radlińska, "the gossiping Warsaw groups", or himself? He adopted the attitude of an impartial, external, and even critical observer of the conference, and at the same time he was one of its most important participants! Was the opinion, which he formulated only in private notes, an expression of the aforementioned "political pragmatism"?

\section{III}

The conference was opened by two introductory speeches: By Jan Szczepański and Tadeusz Kotarbiński, the chairman of the conference. 
Already in these first statements there was an attempt to present social pedagogy, as well as social policy, in a new, current political context. In his Słowo wstepne [Foreword] to the conference, discussing the objectives of the conference, Szczepański stressed the issue of the relationship between science and practicing social life and the functioning of the state. In the socialist society and its state agendas - he noted - there are institutions professionally prepared to solve social problems. Why then - he asked relata refero - yet more efforts and new staff? And he answered this question in a way that was as sophisticated as it was ideologically convincing. He pointed out, in the first place, the need for government officials to develop a "scientific view of social life"; after all, it was not without reason that the Marxist variety of socialism was complemented by the word "scientific". At the same time, the aim was probably to increase the professionalism of clerks, their forms and methods of work, as well as to reduce or eliminate the top-down, formal attitude of clerks towards the "citizen". One can think that this was an echo of the postulate of "socialism with a human face", submitted in the first phase of the "political thaw of October 1956".

The second argument, which Szczepański used to define the mission and goals of the conference, was also of a scientific and pragmatic nature. He claimed, referring to the classic thesis presented by Radlińska, that there are no wider social changes without transformations in microenvironments of life of people, and appropriately educated employees - clerks, social activists, educators and caretakers - will be helpful in stimulating such changes. That is why, as was the conclusion of this argument, the conference is a meeting of four categories of people: "people of science", "practitioners of various kinds", activists running various institutions of help and simply "active people". The aforementioned were to be characterized - and this is the continuation of the return to the popular concepts of Radlińska - by knowledge, "the need of the heart", humanistic and humanitarian motives, individual approach to another human being, and even "deep affection and sympathy for suffering human beings". They were to be specialists in economic matters and to be able to stimulate social forces without which there can be no economic growth. If this thesis contained also clear tasks in the field of traditional social assistance and activization, then Szczepański's next comments could no longer raise any ideological objections. "We are - as he wrote clearly and explicitly - a society building a socialist system, we have more than twenty years of experience behind us, we are proud of the successes achieved during this time [...] A socialist society is to [...] be a self-governing society of enlightened and kind people" (Szczepański 1968, p. 11). 
The speech of T. Kotarbiński also made references to socialism. However, the comments he made on this subject were far from Marxist orthodoxy. The speaker began with the notion of social pedagogy, which he described as a science dealing with the "educational content" of the activities of various social institutions, and not only schools. He then recalled the names of people who, in his opinion, had been involved in social pedagogy in the past, i.e. were engaged in out-of-school cultural work, assistance and social care, who "fought ignorance" and shaped "the spirit of fair coexistence" among people. In this group he included: Wacław Nałkowski, Stanisław Michalski, Edward Abramowski, Ludwik Krzywicki, Teodor Vieweger, Stefania Sempołowska, Władysław Spasowski. All of them, although active in different times and representing different, sometimes contradictory ideological orientations, "went through socialism" - Kotarbiński concluded. It is easy to notice that in the gallery of people mentioned above, the majority of them were non-Marxists. One had to have the respect and independence of Kotarbiński in order to publicly speak about "socialists" from outside the circle of party Marxists at that time. The group of the mentioned "socialists" also included Helena Radlińska. Referring to the cooperation with Radlińska, which began in 1945 at the University of Łódź, Kotarbiński described her in words that went beyond the framework of a perfunctory profile, that is:

Helena Radlinska devoted herself to the struggle of the Polish nation for reunion and independence, to the struggle for a just system and for the universality of participation of the broadest social classes in material and spiritual goods and in the co-governance of the Republic of Poland. However, she was confronted with a different interpretation of independence and justice, and a different democracy than the one she had been familiar with throughout her life, and the differences between these positions, not so evident at first, became clearer and clearer, which was, in fact, due to certain elements of conservatism in her philosophical view of the world. But Helena Radlinska was not one of those who were afraid of repression. Despite the difficulties, the Institute of Social Pedagogy under her leadership, terminated against her plans in 1950 [the closure of the Institute on the basis of political decisions - comment by WT], managed to guide 116 candidates to exams and master's theses, five people to obtain PhD diplomas, one to the postdoctoral procedure. [She is a person of] a great heart and devoted to the idea of the superiority of intellect

- Kotarbiński concluded his speech (1968, p. 16).

In 1967, the "controversial social pedagogy", to which Szczepański was so clearly distancing himself, and its "socialist" creator was spoken about not only during the conference in question. Łukasz Kurdybacha, a professor at 
the University of Warsaw, known for his commitment to the party, also spoke on this subject. In his book with a "strong" ideological title Wplyw Rewolucji Październikowej i szkoły radzieckiej na polska myśl oświatowa 1918-1939 [The Influence of the October Revolution and the Soviet School on Polish Educational Thought 1918-1939], he classified Radlińska, as well as the circle of liberaldemocratic pedagogues she represented, as "people sensitive to social harm and looking for measures to counter it". The well-known book Społeczne przyczyny powodzeń i niepowodzeń szkolnych [Social causes of school successes and failures] prepared under Radlińska's supervision, was recognized by him as "an objective, extremely accurate, comprehensively justified and insightful attack on the capitalist system of Poland in the interwar period". (Kurdybacha 1967, p. 283 et seq.).

This opinion, rehabilitating Radlińska and her work, eliminated from social circles the voices of not so distant past, in which social pedagogy was described as "bourgeois pedagogy", a discipline which before the year 1939 took part - even! - in the "fascistization of the country" (Mysłakowski, Szaniawski 1953). However, the attacks on this discipline of education sciences, usually based on ideological rather than content-related positions, will continue in the years to come. Some will continue to argue that this is a "bourgeois" discipline. Others, among them prominent party activists at universities, consider social pedagogy to be subordinate to the ideology of real socialism (see Kawula, 2012, pp. 13-23).

If, after the speeches of Szczepański and Kotarbiński, any of the attendees of the conference still had questions as to the ideological roots of this meeting, then Szczepański's next speech Otwarcie konferencji [Opening the Conference] did not leave any doubts in this respect. The words said then were as if taken from a propaganda banner: "we want to implement our goals and plans for economic and cultural development established by the Party and the Government". (Szczepański 1968, pp. 17-18). Also in Uwagi od redakcji [Notes from editors], published in the aforementioned periodical of the TWWP "Człowiek w Pracy i w Osiedlu" [Man at Work and at Home] (1968, no. 1), opening the post-conference publication, a new message was added with the use of the principled communist terminology: "The main factor in the education of a man and transformation of the environment is the revolutionary labor movement that builds a new system and thus creates a new environment and a new man" (Od redakcji, p. 7). Thus, Radlińska's wellknown thesis, the foundation of the concept of democratic and civic social pedagogy, that education transforms the environment with the forces of this environment - in the name of an ideal - was accepted, transformed, taken 
over and introduced into a new political project called "socialist democracy" by the supporters of the "new faith".

\section{IV}

The topic of the conference was broadly developed in the main lectures, which - probably not by chance - presented various perspectives: academic and at the same time relatively neutral politically, as well as practical and politically engaged. Was such a contrast between the issues raised intended? - it is possible. This is because it created a situation of open and dynamic discourse. The first of these perspectives included the lectures of R. Wroczyński and A. Kamiński, and the second one of Maksymilian Siemieński (who died in 1966), A.O. Uziembło and Edmund Szubert.

Only the title of Wroczyński’s extensive paper Pedagogika społeczna, jej podstawowe pojęcia oraz rozwój problematyki [Social Pedagogy, its basic concepts and the development of the issue] clearly indicated the academic, scientific and not socio-political character of this presentation. The starting point here was a broad concept of education, understood as a socio-cultural process that goes beyond school education and embraces man in the whole course of life. This approach was fundamentally different from that of school education at that time, which was organized top-down and carried out in compliance with the policy. The broad definition of education gave rise to new tasks and new core areas of pedagogical work: adult education and social welfare. This, in turn, led to the creation of the following fields of social pedagogy: family pedagogy, work pedagogy, education of consumers of cultural goods, health education, free time pedagogy, social and educational counseling. In the second step, in a way, answering the question: who is to implement such a broad profile of tasks, Wroczyński presented a profile of the "organizer of educational processes", i.e. a care and educational and social worker. This meant returning to the findings of Radlińska, pursued since 1925 at the College of SocialEducational Work at the Free Polish University (Wolna Wszechnica Polska) in Warsaw, where Radlińska taught social workers; many leading graduates of this university took part in this conference.

One of the main points of Wroczyńskis speech was an attempt to break the model of the traditional concept of school, in place of which he proposed the concept of the so-called community school. Wroczyński commented on the relationship between school and the environment already in the early 1960s. At that time he began to combine his existing research on the history of education and pedagogical thought with the development of a modern concept 
of the school - the center of cultural life of the local environment, linked to social needs and open to the environment. Such a school goes beyond the limits of didactic activities, deepens relations with the environment, organizes free time and extra-curricular activities for students, cooperates with parents. Teachers of such a school also deal with social prevention, compensation and environmental animation in their environment. They strive both to prevent the occurrence of factors threatening the development of the young generation and to equalize the effects of unfavorable environmental conditions (Wroczyński 1968).

A community school had already been discussed by Wroczyński as early as in 1964 in the script Wprowadzenie do zagadnien pracy oświatowej [Introduction to the issues of educational work], in order to expand this concept in various subsequent publications, including the textbook Pedagogika społeczna [Social Pedagogy] (1974, 1976, 1979, 1984). The issue of a community school was one of the central elements of the environmental theory of social pedagogy developed at that time (see: Wroczyński 1960a; 1960b; Winiarski 2015; 2017, pp. 247-266; Smolińska-Theiss 2016; 2018, pp. 513-522). While developing his position, Wroczyński broadly referred to Polish school and educational traditions, used rich Western literature, and also included references to Russian sources. By demonstrating the universality of social pedagogy and its presence in Europe, he formed a barrier against attempts at direct indoctrination of this discipline. In this way, he also created a sphere of his own scientific freedom.

In his paper entitled Czas wolny w świetle pedagogiki społecznej [Free time in the light of social pedagogy] Aleksander Kamiński, in contrast to Wroczyński's broad and theoretical position, presented a narrower and more practical picture of social pedagogy. If the first of these approaches defines social pedagogy as a pedagogical direction (next to e.g. cultural pedagogy, psychological pedagogy or Marxist pedagogy), then in the second case it is an educational theory of social work, covering the issues of social work and adult education. Such a perspective is only seemingly narrow. It covers a wide range of issues of social aid, educational care and development support, as well as of leisure time.

Narrow academic and formal reflections on the notion of social pedagogy gained more specificity when Kamiński combined the issue of holidays and educational organization of free time for children and youth with urban and health issues. A visible sign of the social transformations of those times, aimed at building a "new society", living in new socio-cultural conditions, was a housing estate lacking its own cultural identity. The housing estates built around work establishments, the large and small projects of socialism, often 
inhabited by newcomers from other regions of the country, were a kind of social desert, an area deprived of individual features. Kamiński saw a remedy for this situation in the broad environmental education. He postulated: "a revival of the neighboring community with its multiple benefits for the inhabitants of all age groups [...]" and added: "And because a housing estate is a primary site of holidays of its inhabitants, housing estate pedagogy is to a large extent a holiday pedagogy". (Kamiński 1968, p. 42).

The analysis of selected social problems, developed by Kamiński, was beyond the institutional dimension of "pedagogy of holidays and supporting development". He paid particular attention to the issue of social maladjustment of youth, the need for alcohol prevention programs and the needs of the elderly. In a similar spirit, emphasizing the problem of breaking the norms of social conduct, was the opinion expressed in a discussion at the conference by Jan Konopnicki (Konopnicki 1968).

Kamiński's speech was a very good "proof" of the possibilities of social pedagogy. It revealed the committed nature of this discipline. The criticism of the social pedagogue went here hand in hand with a project of positive changes. Despite the then prevailing model of top-down, directive-based management of social life, Kamiński stressed the particular cultural and educational significance of the family and the neighboring (local) community. This meant a direct link with the roots of social pedagogy.

The position of Maksymilian Siemieński, who was partly in opposition to social pedagogy, and also to Wroczyński’s and Kamiński’s speeches, was based on the assumption that - firstly - the currently expanding scope of education goes beyond the scope of school and child issues, and secondly - education is a social activity "taking place in society and for society". Hence the superior conclusion: there is no such pedagogy - especially "in the socialist system" which in its essence, assumptions and functions is not social pedagogy.

The author expressed an opinion that Radlińska's social pedagogy, which in its time was progressive, is now only of historical significance and cannot be included in any field of pedagogy in the new system. There is also no clarity as to whether this is a faculty or a specialization within pedagogy, and - what is perhaps the most important - the subject of social pedagogy does not exist, because its issues belong to other social sciences and disciplines within pedagogy. The criticism also concerned the name "social pedagogy". This term is too broad and if kept, it would in fact cover the whole life of adult people, it would become some kind of overarching, ubiquitous and universalist science, which is simply unjustified and impossible. Finally, as was the crowning argument, the development processes of the socialist society, the 
dynamics of the "epoch of cultural revolution and mass culture", exceed the scope of the theory and practice of social pedagogy.

Therefore, we need "a new social pedagogy" - this is the thought concluding a critical part of Siemieński's opinion. On the positive side, however, there was a project of "future, social and socially oriented" pedagogy. The basis for this proposition was a clear division of "educational matters" into "school" and "out-of-school"; the latter were assigned to social pedagogy. The proposed solution was to make the existing area of social pedagogy, which was only a "conglomerate of random issues and issues", more precise. The postulated social pedagogy will contribute - apart from school and outof-school pedagogy - to the "general theory of human education", covering "educational needs of all age groups, professions, situations and environments". A separate place, independent of social pedagogy, was to be taken by adult education. Also Franciszek Urbańczyk pointed to the growing scientific independence of adult education and its achievements in the People's Republic of Poland during the conference discussion (Urbańczyk 1968).

Although Siemieński's thesis was critical and polemical towards social pedagogy, it did not mean the elimination of this discipline. It was also not a strictly political statement, subordinate to party and government orders. In this perspective, social pedagogy was supposed to help solve current educational problems and support "socialist social reconstruction", bringing as stressed by Siemieński - positive changes in culture and education. It was also essential in the pedagogical planning and conducting of out-of-school education. These tasks focused on "educating the man of the future", were to be carried out in cooperation with other social sciences (Siemieński 1968a; 1968b).

The same compromise trend in understanding and transforming social pedagogy included the conference speeches of the aforementioned subsequent speakers: Uziembło and Szubert. The first of them was a well-known social figure. Teacher and soldier, mathematician and pedagogue, communist and democratic opposition activist in the 1970s and 80s, always presented an attitude called "service to ideas".

Without much explanation, Uziembło placed the history of social pedagogy, seen from the point of view of its ideological orientation, theoretical and methodological assumptions and social involvement, within the scope of socialist pedagogy. He elaborated on this subject as follows:

It [social pedagogy - WT] drew vital juices from the real struggle of the working class and peasant masses, took over the methods of research and the point 
of view of theoreticians of class struggle and was subject in the performance of its tasks to all the limitations that resulted from the influence of bourgeois ideology and from the conditions of social life in which its creators had to operate. (Uziembło 1968, p. 82).

This effective evaluation, which was probably important for many conference participants, was in fact an overinterpretation and projection of certain facts from the history of social pedagogy, and in a formal sense a way of extracting and showing the value of social pedagogy and "installing" it in the realities of the socialist system. Uziembło's further argument focused only on the positives of the "modified", i.e. politically purified and improved social pedagogy. The subject of this discipline is - according to the lecturer "intensifying education", different from the classical teacher-pupil relationship ("initiating education"). It is, in a way, "atypical", because it takes place among all social relations and also affects "mature" people. Social pedagogy understood in this way performs (may perform) the following tasks: supporting the development of activity of "mature man", compensating for deficiencies in the development and education of children and youth, environmental support, understood as strengthening positive influences and weakening negative environmental stimuli.

Uziembło proposed and implemented "social pedagogy in action", a discipline as close to life as possible, focusing on existing educational, pedagogical, cultural, community, economic and social needs. The symbolic and actual center of this pedagogy was the aforementioned Polish Free University Association in Warsaw.

The activity of the Polish Free University Association was the subject of the last of the plenary lectures of the conference, the author of which was the aforementioned Edmund Szubert. In Szubert's opinion, probably shared by many former visitors, graduates and employees of the University, the progressive and democratic tradition of this institution continued to serve the country. Even in the different social and political conditions of a socialist state. This was evidenced by the rich didactic, scientific and publishing activity of the Association highlighted by the speaker.

The presentation had to include references to the party's current policy, direct or indirect assurances about the participation "in socialist construction", "shaping political awareness in the spirit of socialism", "strengthening the ideological offensive", "recognizing the problem of man in industry", reconstruction and construction of the disappearing "moral backbone". It was a time, as Szubert stressed, of "a renaissance of interest in social issues" 
and "recognizing the problem of man", a time of long-term changes in which the Polish Free University Association actively and professionally participates (Szubert 1968).

In the 1960s social sciences, including pedagogy and social pedagogy, were both in the sphere of relative freedom and of ideological and administrative control. The analyzed 1967 conference was a symbolic gate between the two mentioned spaces. The first of these areas, although to different degrees and with different intentions, was noticed and highlighted by all the speakers mentioned here. It covered the history and tradition of social pedagogy, showed the solidarity and socialist ethos of this discipline, its theoretical maturity, the possibilities of socio-educational practice, as well as - indirectly - the environment of people who created and practiced social pedagogy, including both professionals and social activists. What is very important, this topic was expressed in an open and honest way, without self-censorship and without economic simplifications or falsifications. Such a position was taken especially by Wroczyński and Kamiński.

Who were the addressees of the lectures emphasizing the ideas of freedom and justice of "old social pedagogy"? To party decision-makers, academic pedagogues, numerous educationalists - "local activists" gathered there? By some, this burden of tradition could be perceived as an insignificant page in history or as a kind of threat in the sphere of ideology, revealing, for example, different faces of socialism. Others had reasons to be proud, gained support, made sure that their commitment and work had beautiful and long roots, the assumptions of which are still relevant. It was an important capital mobilizing for further action.

The mechanisms of ideological and administrative control - the second of the above-mentioned areas of functioning of social pedagogy were the principles of the communist system and involvement in "socialist reconstruction and construction", change of social structure and social awareness. In this case, the reception of the content of the conference and its evaluation was polarized, adopting - one time - the form of a fundamental criticism of the historical past of social pedagogy (fragments of speeches by Szczepański, Kotarbiński, Siemieński, Uziembło and Szubert), the other time the form of a compromise approach, based on the recognition of the need to build a "new" social pedagogy, located between its "historical" and "socialist" dimensions. This resulted in, if not the elimination of the achievements of social pedagogy, a significant reduction in the presence of the "old" social pedagogy in the new realities (some elements of Siemieński's speech). 
At the symbolic crossroads between the mentioned spheres of "freedom" and "criticism" a "third quality" emerged, a new look at the place and role of social pedagogy in the existing political and social conditions. This is because the conference was a broadly understood platform for dialog and confrontation, search and comparison, voices of criticism and approval. It was not a meeting intended to "destroy the enemy"; both sides - although to a different degree and for different purposes - sought a compromise. The designed new identity of social pedagogy, which did not mean the elimination of "old" social pedagogy, in the sphere of axiology accepted the ethos of social service, an action leading to "social progress", developing also the conditions for optimal development of each citizen. In this context, the innovative tasks of the "new social pedagogy", such as socialization of school (Wroczyński), organization of free time for children and youth (Kamiński), the idea of lifelong learning (Siemieński), "intensifying education" (Uziembło), are still noteworthy, even today. Another part of this proposal was related to undertaking the so-called urgent social problems and solving them with the help of social pedagogy, such as: alcoholism, social maladjustment of youth, social anomaly of large housing estates, aging of the society. Various substantive and non-substantive factors will make this transitional form of Polish social pedagogy of the 1960s and 1970s to be described by some as "pedagogy in the service of socialism" and by others as "bourgeois pedagogy".

\section{References}

Bieńkowski W., 1978, Socjalizm po 60 latach, Instytut Literacki, Paryż.

Degen D., Hübner P., 2006, Polityka naukowa władz Polski Ludowej w zakresie humanistyki (1945-1990), [in:] Humanistyka polska w latach 1945-1990, eds. U. Jakóbowska, J. Myśliński, Instytut Badań Literackich, Warszawa, pp. 11-38.

Hirszowicz M., 2001, Pułapki zaangażowania. Intelektualiści w służbie komunizmu, Wydawnictwo Naukowe Scholar, Warszawa.

Kamiński A., 1968, Czas wolny w świetle pedagogiki społecznej, “Człowiek w Pracy i w Osiedlu", 1, pp. 36-57.

Kawula S., 2012, Pedagogika społeczna. Dzisiaj i jutro, Wydawnictwo Edukacyjne Akapit, Toruń. Konopnicki J., 1968, Wybrane zagadnienia niedostosowania społecznego dzieci i młodzieży, "Człowiek w Pracy i w Osiedlu”, 1, pp. 148-150.

Kotarbiński T., 1968, [Przemówienie profesora...], “Człowiek w Pracy i w Osiedlu”, 1, s. 9-13.

Kraśko N., 1996, Instytucjonalizacja socjologii w Polsce 1920-1970, Wydawnictwo Naukowe PWN, Warszawa.

Kurdybacha Ł., 1967, Wpływ Rewolucji Październikowej i szkoły radzieckiej na polską myśl Oświatowa 1918-1939, PWN, Warszawa.

Listy Aleksandra Kamińskiego i Adama O. Uziembły. 1965-1975, 1997, [in:] Listy o pedagogice społecznej, ed. W. Theiss, Wydawnictwo Akademickie “Żak”, Warszawa, pp. 184-245. 
Lutyński J., 1990, Nauka i polskie problemy. Komentarz socjologa, Państwowy Instytut Wydawniczy, Warszawa.

Misztal B., 2000, Teoria socjologiczna a praktyka społeczna, Universitas, Kraków.

Modrzewski J., Sipinska D., 2013, Meandry polskiej zinstytucjonalizowanej socjologii wychowania, [in:] Od przeszłości ku nowym horyzontom. W kręgu historii socjologii, eds. Kaczmarek J., Przestalski A., Wydawnictwo Naukowe UAM, Poznań, pp. 103-126.

Przyszczypkowski K., 2012, Polityczność (w) edukacji, Wydawnictwo Naukowe UAM, Poznań.

Siemieński M., 1968a, Nauki pedagogiczne a potrzeby i nauki społeczne, "Człowiek w Pracy i w Osiedlu", 1, s. 58-80.

Siemieński M., 1968b, Przedmiot i zakres pedagogiki, “Człowiek w Pracy i w Osiedlu”, 1, 143-147.

Smolińska-Theiss B. (ed.), 2016, Szkoła w środowisku, środowisko szkoły, "Pedagogika Społeczna", no. 2.

Smolińska-Theiss B., 2018, Szkołocentryczny model pedagogiki społecznej Ryszarda Wroczyńskiego, [in:] Srodowiska uczestnictwa społecznego jednostek, kategorii i grup społecznych, eds. J. Modrzewski, A. Matysiak-Błaszczak, E. Włodarczyk, Wydawnictwo Naukowe UAM, Poznań, pp. 513-522.

Smolińska-Theiss B., Theiss W., 1998, Pedagogika społeczna a polityka, [in:] Pedagogika społeczna jako dyscyplina akademicka. Stan i perspektywy, eds. E. Marynowicz-Hetka, J. Piekarski, E. Cyrańska E., Wydawnictwo Uniwersytetu Łódzkiego, Łódź, pp. 172-180.

Szczepański J., 1954, Helena Radlińska, “Życie Szkoły Wyższej”, 12, pp. 147-149.

Szczepański J., 1968, Słowo wstępne, “Człowiek w Pracy i w Osiedlu”, 1, pp. 9-13.

Szczepański J., 2013, Dzienniki z lat 1945-1968, opracowanie, wstęp i przypisy D. Kadłubiec, Galeria Na Gojach, Ustroń.

Sztompka P., 2002, Socjologia. Analiza społeczeństwa, Wydawnictwo Znak, Kraków.

Szubert E., 1968, O działalności Towarzystwa Wolnej Wszechnicy Polskiej, "Człowiek w Pracy i w Osiedlu", 1, pp. 116-134.

Theiss W., 1997, Radlińska, wyd. 2, Wydawnictwo Akademickie “Żak”, Warszawa.

Theiss W., 1998, Adam Olgierd Uziembło: między polityką a pedagogiką, "Bobolanum", 9, pp. 203-222.

Theiss W., 2007, Uziembło Adam Olgierd, [in:] Encyklopedia pedagogiki XXI wieku, Vol. 6, ed. T. Pilch, Wydawnictwo Akademickie “Żak”, Warszawa, pp. 1197-1198.

Theiss W., 2018, Edukacja i zaangażowanie. Sto lat pedagogiki społecznej w Polsce (1908-2008). Wprowadzenie, "Pedagogika Społeczna", 2, s. 9-34 [Education and Commitment. One Hundred Years of Social Pedagogy in Poland (1908-2008). Introducation, "Social Pedagogy", 2, s. 35-60].

Urbańczyk F., 1968, Niektóre problemy kształcenia dorosłych, “Człowiek w Pracy i w Osiedlu”, 1 , pp. $135-138$.

Uziembło A., 1968, Rola i osiagnięcia pedagogiki społecznej w Polsce Ludowej, “Człowiek w Pracy i w Osiedlu", 1, pp. 81-115.

Winiarski M., 2015, Szkoła środowiskowa i jej obecność w edukacji równoległej, permanentnej i środowiskowej, "Pedagogika Społeczna", 3, pp. 53-76.

Winiarski M., 2017, W kręgu pedagogiki społecznej. Studia - szkice - refleksje, Społeczna Akademia Nauk, Łódź-Warszawa.

Wroczyński R., 1960a, Szkoła i środowisko, “Kwartalnik Pedagogiczny”, 1, pp. 3-19.

Wroczyński R., 1960b, O pojmowaniu środowiska i jego konsekwencji dla wychowania, "Kwartalnik Pedagogiczny", 4, pp. 33-44.

Wroczyński R., 1968, Pedagogika społeczna, jej podstawowe pojęcia oraz rozwój problematyki, “Człowiek w Pracy i w Osiedlu”, 1, pp. 19-35. 